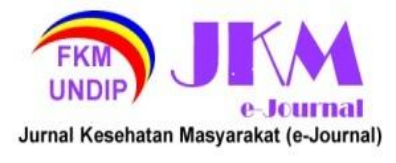

JURNAL KESEHATAN MASYARAKAT (e-Journal)
Volume 9, Nomor 6, November 2021
ISSN: 2715-5617 / e-ISSN: 2356-3346
http://ejournal3.undip.ac.id/index.php/jkm

\title{
HUBUNGAN TUTUP KONTAINER, BAHAN KONTAINER, DAN SUMBER AIR DENGAN TINGKAT KEJADIAN DBD DI WILAYAH KERJA PUSKESMAS NOGOSARI KABUPATEN BOYOLALI
}

\author{
Choirun Nisa ${ }^{1^{*}}$, Lintang Dian Saraswati ${ }^{2}$, Martini Martini ${ }^{2}$, Mateus Sakundarno Adi $^{2}$ \\ ${ }_{1}^{1}$ Peminatan Entomologi Kesehatan Fakultas Kesehatan Masyarakat Universitas Diponegoro \\ JI. Prof. H. Soedarto, S.H.,Tembalang, Semarang, Indonesia \\ ²Bagian Epidemiologi dan Penyakit Tropik Fakultas Kesehatan Universitas Diponegoro \\ JI. Prof. H. Soedarto, S.H.,Tembalang, Semarang, Indonesia \\ *Corresponding author: choirunnisa673@gmail.com
}

\begin{abstract}
The vectors that cause dengue fever usually live in habitats close to humans, one of which is a water reservoir (TPA) or commonly called a container. In Glonggong Village, containers and water sources are still a problem that triggers the density of larvae. This study aims to determine the relationship between container lids, container materials, and water sources on the incidence of DHF. The total sample used is 110 houses with a total of 201 containers. Collecting data using visual larval techniques, namely only by observing containers that are positive for larvae. Based on the results of the relationship test, it was found that the proportion of the presence of the lid was $p=0.071$, container material was $p=0.163$, and water source was $p=0.590$. Which means that there is a relationship between container lids, container materials, and water sources with the incidence of DHF. Thus, there is a need for further socialization regarding the $3 \mathrm{M}$ Plus program in order to suppress dengue cases in Glonggong Village.
\end{abstract}

Keyword: Container, Larvae, DHF, Cases

\section{PENDAHULUAN}

Pertumbuhan nyamuk Aedes aegypti dipengaruhi oleh kondisi lingkungan sekitar serta tempat perindukan. Tempat perindukan alami yang potensial sebagai tempat pertumbuhan nyamu Aedes aegypti yaitu lubang bebatuan, batok kelapa, lubang pohon, pelepah pisang dan masih banyak lagi. Lalu, untuk tempat perindukan buatan atau non alami yaitu ember, bak mandi, botol bekas, kaleng bekas, drum, dan tandon air lainnya. Menurut penelitian putri dkk (2016), sumur dan gentong (terbuat dari tanah liat) menjadi tempat yang potensial untuk perkembangbiakan vektor DBD. (1) (2)

Tempat yang disukai nyamuk Ae. Aegypti adalah air jernih seperti kontainerkontainer yang ada disekitar kita. Tempat Penampungan Air (TPA) adalah tempat penampung air yang digunakan oleh masyarakat sekitar untuk keperluan sehari-hari seperti masak dan mandi. Contoh TPA adalah tandon air, bak mandi dan masih banyak lagi. TPA tersebut berpotensi menjadi tempat perkembangbiakan larva Aedes. Apabila tandon terbuka, maka larva mudah berkembangbiak. Selain itu, masih banyak masyarakat yang memanfaatkan sumur gali untuk kebutuhan sehari-hari, hal ini memicu terjadinya perindukan alami nyamuk dan memudahkan untuk bertelur disana.(3)(4)

Berdasarkan keterangan dari puskesmas dan warga setempat, penampungan air yang digunakan oleh penduduk sekitar tidak memiliki tutup atau tidak ditutup serta masih banyak masyarakat yang memanfaatkan sumber air alami seperti sumur. Hal ini memungkinkan terjadinya perkembangbiakan nyamuk Aedes aegypti. Wilayah Nogosari juga menjadi salah satu wilayah endemis DBD di Kabupaten Boyolali(5). Dengan latar belakang tersebut, maka perlu adanya penelitian survei kepadatan larva di Desa Glonggong.

\section{METODE PENELITIAN}

Penelitian ini merupakan penelitian observasional analitik dengan pendekatan cross sectional. Metode yang digunakan dalam penelitian ini adalah dengan metode probability, dengan pendekatan sytematic random sampling.

Pengambilan sampel minimal sebesar 100 rumah atau kepala keluarga. Jumlah rumah 100 ditambah dengan 10 rumah sebagai buffer untuk toleransi kesalahan $10 \%$. Dari uraian tersebut maka jumlah sampel sebanyak 110 rumah. Dari 110 rumah yang diamati total kontainer yaitu sebesar 201 kontainer. ${ }^{(6)}$ 


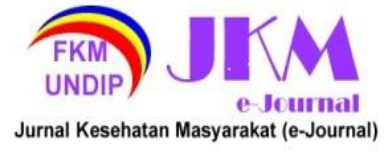

Pengumpulan data menggunakan teknik survei dengan door to door di rumah-rumah yang masuk sebagai sampel. Data yang didapatkan selanjutnya di analisis dengan uji Chi-Square menggunakan program komputer.

HASIL DAN PEMBAHASAN

A. Hubungan Keberadaan Tutup dengan Kejadian DBD
JURNAL KESEHATAN MASYARAKAT (e-Journal)

Volume 9, Nomor 6, November 2021

ISSN: 2715-5617 / e-ISSN: 2356-3346

http://ejournal3.undip.ac.id/index.php/jkm

Tabel 1. Analisis Hubungan Keberadaan Tutup dengan Kejadian DBD

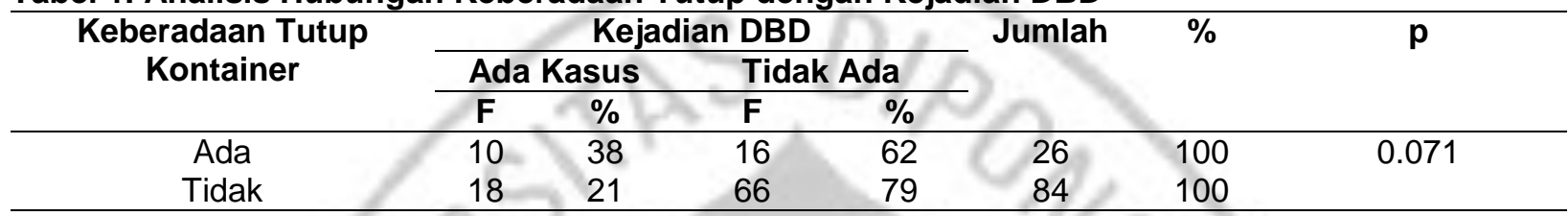

Berdasarkan hasil analisis uji hubungan menggunakan Chi Square, nilai $p=0,071$ yang dapat diartikan bahwa terdapat hubungan bermakna antara keberadaan tutup dengan kejadian DBD. Hal ini tidak sejalan dengan penelitian yang dilakukan di Kecamatan Baturaja pada tahun 2012 yang menyebutkan bahwa tidak ada hubungan signifikan antara keberdaan tutup dengan kejadian DBD. ${ }^{(7)}$

Penelitian lain yang sejalan telah dilakukan di Kota Makassar tahun 2004 yang menyatakan bahwa terdapat hubungan antara keberadaan tutup dengan kejadian DBD. Keberadaan tutup di wilayah tersebut sangat
Nyamuk Aedes sp. suka meletakkan telurnya di kontainer yang terbuka, sehingga ketersediaan tutup dapat berpengaruh terhadap perkembangbiakan telur nyamuk. ${ }^{(7)}$ Nyamuk sangat menyukai tempat yang terlindung dari sinar matahari, maka dari itu peran tutup kontainer untuk melindungi air sangat berpengaruh terhadap keberadaan larva

tersebut sangat
diperlukan untuk menekan perkembangbiakan larva. ${ }^{(8)}$

angka

B. Hubungan Bahan Kontainer dengan Kejadian DBD

Bahan kontainer memiliki resiko terhadap keberadaan jentik yaitu semen dan keramik. Hal ini terjadi karena semen dan keramik cenderung tidak dapat merefleksikan cahaya sehingga tidak ada cahaya yang masuk ke dalam kontainer. Selain itu kondisi minim cahaya dapat mengakibatkan kontainer berlumut dan sulit dibersihkan. Refleksi cahaya rendah dan suhu dapat menyebabkan perkembangbiakan nyamuk vektor DBD. ${ }^{(8)}$

Tabel 2. Analisis Hubungan Bahan Kontainer dengan Kejadian DBD

\begin{tabular}{|c|c|c|c|c|c|c|c|}
\hline \multirow[t]{3}{*}{ Bahan Kontainer } & & \multicolumn{3}{|c|}{ Kejadian DBD } & \multirow[t]{3}{*}{ Jumlah } & \multirow[t]{3}{*}{$\%$} & \\
\hline & \multicolumn{2}{|c|}{ Ada Kasus } & \multicolumn{2}{|c|}{ Tidak Ada } & & & \\
\hline & $\mathbf{F}$ & $\%$ & & $\%$ & & & \\
\hline Semen & 2 & 20 & 8 & 80 & 10 & 100 & 0.163 \\
\hline Plastik & 20 & 26 & 58 & 74 & 78 & 100 & \\
\hline Tanah & 0 & 0 & 8 & 100 & 8 & 100 & \\
\hline Keramik & 6 & 43 & 8 & 57 & 14 & 100 & \\
\hline
\end{tabular}

Berdasakan temuan lapangan, bahan kontainer dari keramik memiliki persentase sebesar $43 \%$ dan berdasarkan hasil analisis uji hubungan menggunakan $\mathrm{Chi}$ square nilai $\mathrm{p}=0.163$ yang artinya terdapat hubungan bermakna antara bahan kontainer terhadap kejadian DBD.

Hal ini sejalan dengan penelitian yang telah dilakukan di Kota Bekasi pada tahun 2018 yang hasil nilai $p=0,001$ dan dapat disimpulkan bahwa terdapat hubungan bermakna antara bahan kontainer terhadap kejadian DBD. (9) Namun berdasarkan penelitian yang telah dilakukan, bahan dasar semen dan keramik lebih banyak ditemukan sehingga berpotensi adanya pertumbuhan mikroorganisame pada lumut yang menjadi makanan larva. Dan minimnya refleksi cahaya meberikan peluang terhadap perkembangan larva. ${ }^{(8)}$ 


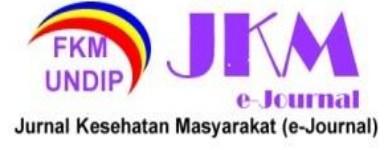

C. Hubungan Sumber Air dengan Kejadian DBD

Larva membutuhkan air sebagai tempat melangsungkan hidupnya. Larva sangat membutuhkan zat-zat organik yang terkandung dalam air sebagai sumber makanannya. Zat-zat
JURNAL KESEHATAN MASYARAKAT (e-Journal)

Volume 9, Nomor 6, November 2021

ISSN: 2715-5617 / e-ISSN: 2356-3346

http://ejournal3.undip.ac.id/index.php/jkm

Tabel 3. Analisis Hubungan Sumber Air dengan Kejadian DBD

\begin{tabular}{|c|c|c|c|c|c|c|c|}
\hline \multirow[t]{3}{*}{ Sumber Air } & \multicolumn{4}{|c|}{ Kejadian DBD } & \multirow[t]{3}{*}{ Jumlah } & \multirow[t]{3}{*}{$\%$} & \multirow[t]{3}{*}{$p$} \\
\hline & \multicolumn{2}{|c|}{ Ada Kasus } & \multicolumn{2}{|c|}{ Tidak Ada } & & & \\
\hline & $\mathbf{F}$ & $\%$ & $\mathbf{F}$ & $\%$ & & & \\
\hline Sumur Bor & 27 & 25 & 80 & 75 & 107 & 100 & 0.590 \\
\hline Air Hujan & 1 & 33 & 2 & 66 & 3 & 100 & \\
\hline
\end{tabular}

Berdasarkan temuan lapangan, sumber air di Desa Glonggong didominasi oleh sumber air yang berasal dari Sumur Bor sebanyak 107 rumah. Namun jumlah rumah positif lebih banyak ditemukan pada sumber air hujan dengan persentase $33 \%$. Berdasarkan hasil analisis uji hubungan dengan Chi Square didapatkan nilai $\mathrm{p}=0.590$ yang artinya dalah terapat hubungan antara sumber air dengan kejadian DBD.

Penduduk Desa Glonggong pada umumnya menggunakan air dari sumur gali atau sumur bor milik pribadi. Namun ada beberapa warga yang tidak memiliki sumur terpaksa harus menadah dan mengandalkan air hujan untuk ditampung. Saat dilakukan penelitian, Desa Glonggong sangat minim air bersih. Dimana air yang dihasilkan dari sumur galian disimpan didalam tandon untuk waktu yang cukup lama. Tentunya hal ini sangat disukai oleh vektor penyebab DBD yaitu Aedes aegypti. Saat dilakukan survei, sumber air yang potensial adanya jentik adalah air hujan sebesar $67 \%$. Hal ini didukung oleh penelitian yang dilakukan di Kelurahan Tamammaung tahun 2015 yang menyatakan bahwa air hujan berpotensi menjadi tempat perkembangbiakan vektor penyebab DBD. (10) Distribusi penularan DBD tidak hanya dipengaruhi oleh indeks kepadatan larva maupun karakteristik kontainer. Banyak faktor-faktor lain yang beresiko menyebabkan penyakit DBD seperti sanitasi lingkungan, kepadatan penduduk, ketinggian tempat, lingkungan biologi, lingkungan sosial dan lain sebagainya.(11)

\section{KESIMPULAN}

1. Hubungan keberadaan tutup terhadap tingkat kejadian DBD dengan nilai $p=0.071$, menunjukkan bahwa ada hubungan antara keberadaan tutup dengan tingkat kejadian DBD organik didapatkan dari sumur gali karena air yang berasal dari sumur gali kaya akan zat organik serta bakteri-bakteri yang dibutuhkan oleh larva. ${ }^{(8)}$
2. Hubungan bahan kontainer terhadap tingkat kejadian DBD dengan nilai $p=0.163$, menunjukkan bahwa terdapat hubungan antara bahan kontainer dengan kejadian DBD.

3. Hubungan sumber air dengan tingkat kejadian DBD dengan nilai $p=0,590$, menunjukkan bahwa terdapat hubungan antara sumber air dengan kejadian DBD.

\section{SARAN}

1. Bagi Perangkat Desa dan Komponen Masyarakat

Senantiasa melaksanakan Program 3M Plus untuk menekan angka kepadatan jentik.

2. Bagi Pemerintah dan Puskesmas Nogosari Perlu adanya program tentang air bersih seperti pembuatan embung agar masyarakat Desa Glonggong kebutuhan air bersih dapat terpenuhi dan juga perlu adanya sosialiasi kepada seluruh masyarakat terkait program $3 \mathrm{M}$ plus secara rutin.

\section{DAFTAR PUSTAKA}

1. Luluk LA. Hubungan Antara Faktor Lingkungan Fisik Dan Perilaku Dengan Kejadian Demam Berdarah Dengue (DBD) Di Wilayah Kerja Puskesmas Sekaran, Kecamatan Gunungpati, Kota Semarang Tahun 2015. J Kesmas. 2015 Nov 30;

2. Kementerian Kesehatan RI. Hubungan kondisi lingkungan dan kontainer dengan keberadaan jentik nyamuk Aedes aegypti di daerah endemis demam berdarah dengue di kota Banjarbaru [Internet]. Badan Litbangkes Kementerian Kesehatan RI. 2013 [cited 2021 Feb 9].

3. Anggie AP. Hubungan Karakteristik Kontainer, Praktik PSN, dan Status Penguasaan Tempat Tinggal Dengan Keberadaan Jenti Aedes sp di Kelurahan 


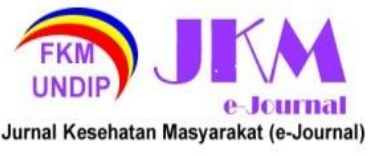

Tembalang Kota Semarang. apps.fkm.undip.ac.id. 2017;

4. Fighi A. Canon, Angela F. C Kalesaran NSHM. Hubungan Antara Kelembapan Dan Curah Hujan Terhadap Angka Kejadian Demam Berdarah Dengue (Dbd) Di Wilayah Kota Manado Tahun 2014-2018 | Canon | KESMAS [Internet]. Jurna Unsrat. 2020

5. Nogosari P. Data Kejadian DBD 2018-2020 Puskesmas Nogosari Kabupaten Boyolali. 2020.

6. BPS. Data Kependudukan Kabupaten Boyolali 2020. boyolalikab.bps.go.id. 2020;

7. Litbang LP, JI Yani KM BA, Sumatera Selatan K, Budiyanto Abstrak A. Karakteristik Kontainer Terhadap Keberadaan Jentik Aedes Aegypti Di Sekolah Dasar [Internet]. Vol. 6, Jurnal Pembangunan Manusia. 2012
Volume 9, Nomor 6, November 2021

ISSN: 2715-5617 / e-ISSN: 2356-3346

http://ejournal3.undip.ac.id/index.php/jkm

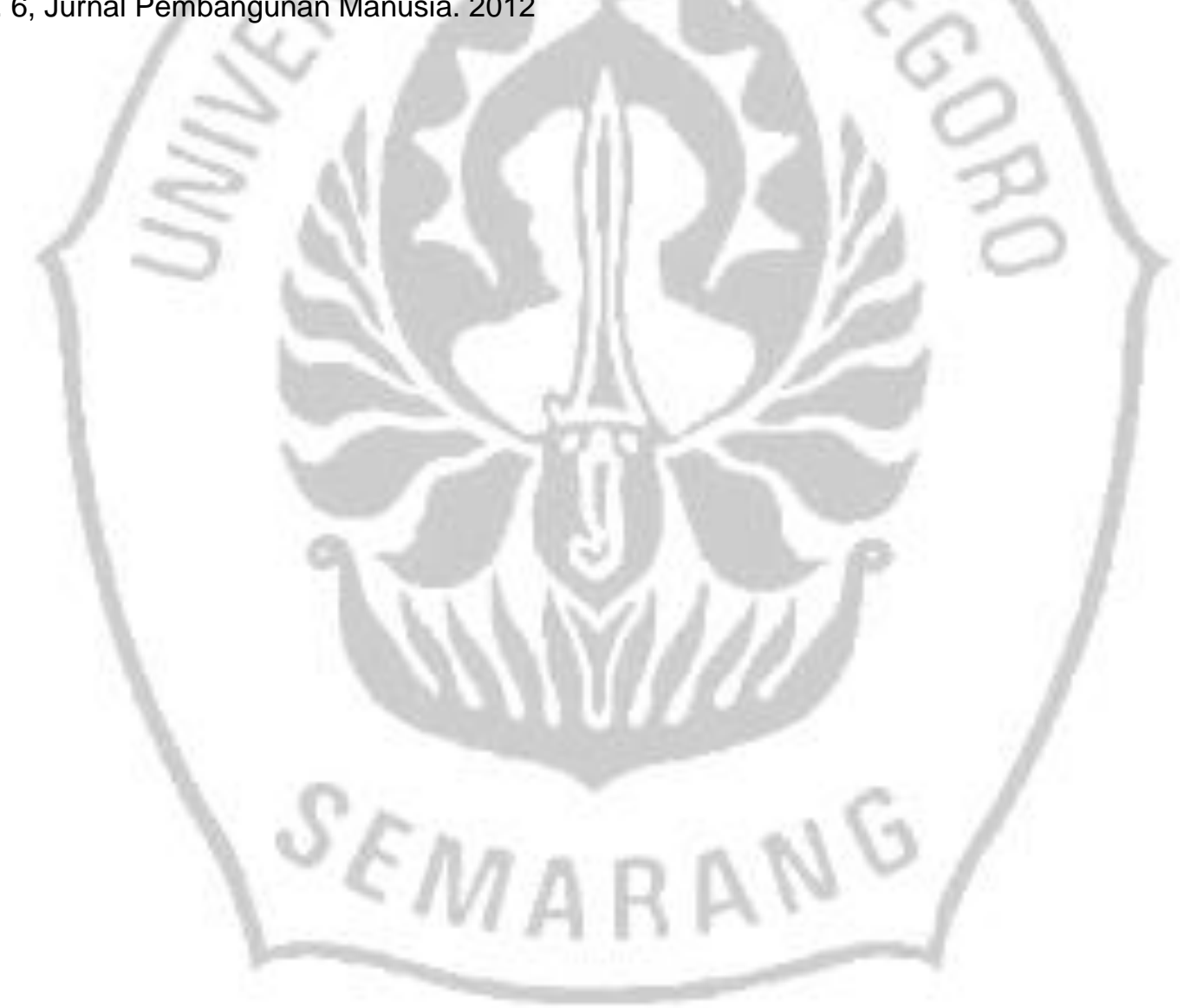

